\title{
Predictors of Pension Finance Literacy: A Survey of Members of Occupational Pension Schemes in Kenya
}

\author{
Amos Gitau Njuguna (Corresponding author) \\ Assistant Professor of Accounting \& Finance, United States International University \\ P.O. Box 14634-0800 Nairobi, Kenya \\ Tel: 254-20-360-6204Ｅ-mail: amnjuguna@usiu.ac.ke \\ John Kennedy Otsola \\ Research Associate, United States International University \\ P.O. Box 14634-0800 Nairobi, Kenya \\ Tel: 254-36-062-0351_E-mail: jotsola@usiu.ac.ke
}

Received: March 21, 2011 Accepted: April 7, $2011 \quad$ doi:10.5539/ijbm.v6n9p101

\begin{abstract}
Pension finance literacy enables individuals to plan for retirement, make proper choices on pension products and contribute effectively in management of their pension schemes. This study sought to determine the pension finance literacy levels and the variables that influence it amongst members of occupational retirement schemes in Kenya. The sample consisted of 2395 (response rate 65\%) individuals drawn from 648 occupational retirement schemes. A binary measure of pension finance literacy was constructed and one way ANOVA and post hoc tests using the Tukey approach were conducted to determine the bases on which pension finance literacy levels differ. The study concludes that pension finance literacy differs significantly on the basis of age, education level, gender, job experience, management level, income, pension plan design, participation in previous pension finance literacy program, area of specialization and membership in a pension plan board but does not differ on the basis of the marital status of the individuals.
\end{abstract}

Keywords: Pension finance literacy, Occupational pension schemes

\section{Introduction}

Financial market advancements of the 21 Century have forced the global financial sector to transfer substantial risks to households as a result of which individuals bear the responsibility to manage their own financial and pension risks. Moreover, the financial landscape has brought about complicated financial products, more flexible regulations and minimal financial disclosures (Messy, 2009) which expose individuals to not only great opportunities to maximize wealth but also more potential to make wrong financial decisions. With minimal pension finance literacy, individuals risk failing to plan for retirement, underestimate their retirement needs, under price pension financial products, undercover retirement risks and incur excessive pension management costs. Indeed, Hastings, Mitchell \& Chyn (2011) conclude that people with lower levels of pension finance literacy rely on employers, coworkers and friends as opposed to cost fundamentals when choosing pension funds.

The unique nature of pension products particularly makes pension finance literacy imperative. The products create long term contracts, which are complicated by uncontrollable factors such as inflation, interest rates, fiscal policies and assumptions of future income (Messy, 2009). Additionally, the changing demographics and systematic trends in the pension industry that are characterized by increased longevity coupled with shorter working lives, decreased public pensions, the shift from defined benefit to defined contribution schemes, increased individual choices and the changing retirement regulations require individuals to have knowledge on pension finance (Arnone, 2004).

Apathy, indifference to pension planning and access to financial education programs form a large barrier to improving people's knowledge of the pension systems and how it affects them (Besley \& Prat, 2005; Worthington, 2005; Skog, 2006; Tippet \& Kluvers, 2007; James, 2009). Evidence from both developing and developed countries indicates that many individuals do not know where to get trustworthy and impartial advice about pension and financial issues, for instance, in the United States of America, where households have a wide 
array of financial products, low levels of financial literacy prevents consumers from making good decisions on financial products and pension systems (Lusardi \& Mitchell, 2006; OECD, 2008; James, 2009; Lusardi, Mitchell \& Curto, 2010).

Financial literacy surveys indicate inadequate pension finance literacy levels amongst the general population. For instance, DFID (2008) reported that only half of the adult population in Africa knew how to use basic financial products and in seven African countries only $29 \%$ of adults had a bank account and $50 \%$ did not use any financial products, not even informal financial products. In $2006,80 \%$ of informal workers did know what a pension was in India; in China, low awareness on the pension arrangement excluded $89 \%$ of the informal workers; in Chile, pension awareness was rated at 2.1 on a scale of 7 and in UK $25 \%$ of the pension credits were not claimed as people did not know that they were eligible; in the US, $50 \%$ of the workers did not make voluntary contributions to pension funds due to lack of awareness and in Japan, 3 million people were not contributors to the national pensions system due to low awareness (Stewart, 2006). Additionally, Chileans were found to have limited knowledge on the pension system in 2010 (Landerretche \& Martinez, 2011). In 2008, only $68 \%$ of retirees in Kenya had knowledge of the benefits they expected on retirement and $80 \%$ of the retirees were never advised on how to spend their retirement benefits and $91 \%$ had never attended pre retirement training (RBA, 2008).

The inimitable nature of pension arrangements and the consequent low level of awareness underscore the importance of pension finance literacy. The present study investigates the predictors of pension finance literacy amongst members of retirement schemes in Kenya. The findings will inform policy makers in the design of pension finance literacy programs as Kenya prepares a national financial literacy strategy. This paper is organized as follows; section 2 provides a literature review, section 3 discusses the research methodology, section 4 discloses the results of the statistical analyses of the data and the consequent discussion of the results while section 5 concludes.

\section{Literature Review}

\subsection{Pension System in Kenya}

Pension systems in Kenya were first put in place after independence in 1963. The first post independent pension fund body, the National Social Security Fund (NSSF), was established in 1965. The pension system in Kenya has been supervised by the independent Retirement Benefits Authority (RBA) since 2000, which oversees the 1997 RBA Act that brought about regulation, protection and structure to the pension fund industry. RBA continues work to develop the industry and advise the government on pension policy reforms. Kenya's pension system embraces four components namely the NSSF, Civil Servants Pension Scheme (CSPS), Occupational Retirement Schemes (ORS) and Individual Retirement Schemes (IRS). Overall the system is estimated to cover $15 \%$ of the labour force and to have accumulated assets of $18 \%$ of the GDP in 2006 (Kakwani, Sun \& Hinz, 2006) and 30\% of the GDP in 2009 (RBA, 2010). The pension system covers an estimated 2 million workers leaving an estimated 5 million workers uninsured under any retirement scheme, of which at least $10 \%$ were at or near the retirement age in 2006 (Kakwani et al, 2006). RBA has succeeded in training over 1,000 schemes with 2611 trustees which accounts for approximately $83 \%$ of the total registered pension schemes in Kenya (Mutuku, 2007). However, this training is only centered on the trustees with the hope that the knowledge and information they acquire will trickle down to the other members of the pension scheme. However, this may not necessarily be the case. Although RBA provides measures to protect individuals by adopting risk based supervision of pension plans, it encourages individuals to customize their retirement savings to their individual requirements, future plans and risk profiles, which necessitates pension finance literacy.

\subsection{Importance of Pension Finance Literacy}

Financial knowledge has been defined as the ability to make informed judgments and to make effective decisions regarding the use and management of money (Worthington, 2005). Remund (2010) on the other hand defines it as a measure of understanding key financial concepts. Financial knowledge enables individuals to build their financial skills and gives them confidence to undertake financial decisions for their pension schemes (Choi, Labson \& Madrian, 2005; Agnew, Szykman, Utkus \& Young, 2007; Tippet \& Kluvers, 2007). Knowledge on savings and plans to save is critical for effective long-term financial decision making that is relevant to pension funds (Landerretche \& Martinez, 2011). Households with low financial knowledge do not plan and so they have lower retirement savings, shorter planning horizons and are less likely to contribute to pension fund's decisions than those with the requisite knowledge (Mitchell \& Utkus, 2003; Lusardi, 2006). Financial knowledge is directly correlated with self beneficial financial behavior and without it individuals will most likely have problems with debt, not save, engage in exorbitant mortgages and will not plan for retirement (Kefela, 2010; Landerretche \& Martinez, 2011; Hastings \& Mitchell, 2011). Financial knowledge has been found to have a strong positive relationship to individual's involvement in pension matters (Moore, 2003), understanding of rights and obligations in pension schemes (Choi et al, 2005), sharpening the risk attitude (Agnew \& Szykman, 2005), increasing savings and investments in complex assets (Lusardi \& Mitchell, 2006) and enhancing innovative ideas (Calvert, Campbell \& Sodini, 2005). Low level of knowledge is associated with limited success 
of voluntary savings schemes, for instance, in Kenya, the lack of a unified financial education program impacts negatively on the general savings culture and low awareness on pension matters (RBA, 2007).

\subsection{Determinants of Pension Finance Literacy}

Arnone (2004) documents that the general population varies according to types of information they need and can process on pension finance. Arnone thus implies that distinct variables like age, education level, gender, job experience, management level, income and marital status influences a person's knowledge on pension finance matters. These factors are discussed in turn;

\subsubsection{Age}

According to Arnone (2004), older individuals are likely to be more knowledgeable on pension finance matters since retirement planning programs are limited to those who are about to retire where the goal of this pre retirement planning program is to help participants identify their basic retirement decisions and start preparing for retirement. Additionally, retirement savings increases with age, which creates consciousness amongst the population as they grow older suggesting that they will seek more of pension finance knowledge (Bell, Carasso \& Steuerle, 2005; Edmiston \& Gillet-Fisher, 2006).

\subsubsection{Education level}

Individuals with higher education have more knowledge on financial and pension matters (Lerman \& Bell, 2006; Hastings \& Mitchell, 2011; Hastings et al, 2011). Hastings et al, attribute the finding to the lack of understanding on basic concepts. Moreover, financial knowledge imparted on the young people form a basis for them to continue with similar education in to the middle age (Lerman \& Bell, 2006). A higher level of education attainment leads to a higher likelihood of participating in a pension plan (Bell et al, 2005) since financial literacy and schooling are significantly correlated.

\subsubsection{Gender}

According to RBA (2005), the knowledge on pension finance differs significantly between men and women as $60.7 \%$ of the men knew the benefits due to them on retirement in contrast to $57.7 \%$ of the women. The low level of pension finance matters by women is attributed to less enthusiasm for, low confidence in and less willingness to learn personal finance than men in addition to being less risk seeking than men (Chen and Volpe, 2002; Zissimopoulos, Karney \& Rauer, 2008).

\subsubsection{Job experience}

The number of years that individuals have worked is positively correlated to the individual's awareness on pension matters (RBA, 2005; Arnone, 2004). Empirical explanations for this lies in the fact that over their working lives individuals accumulate retirement savings and therefore develop interest in the management of the savings. Additionally, as they accumulate years of experience, their retirement dates approach.

\subsubsection{Management level}

The management level in which the employee serves is related to their awareness of retirement issues (RBA, 2005; Edmiston \& Gillet-Fisher, 2006). The studies conclude that high level managers outweigh their counterparts in the lower level management in awareness. Empirical reasons for the finding are linked to the positive correlation between individual's management level and their level of education.

\subsubsection{Income}

Individual's incomes are positively correlated to their knowledge and awareness of pension matters (Lerman \& Bell, 2006; Agnew et al, 2008; RBA, 2008; Hastings et al, 2011). Overall, budget constraints limit the individual's participation in education programs and limit their savings and consequent interest in participating in pension finance education programs. Retirement savings rise in proportion to income and age (Bell et al, 2005). For the low income, savings behavior is difficult to track since many low income people lack consistent attachment to the labor force and are usually employed on seasonal contracts (Bell et al, 2005).

\subsubsection{Marital status}

Married workers participate in pensions at a higher rate than the unmarried workers as a result of low financial literacy levels amongst the unmarried population (Bell et al, 2005; Zissimopoulos, Karney, \& Rauer, 2008). Forenseca, Mullen, Zamarro and Zissimopouulos (2010) support the findings and point out that unmarried, more so divorced women near retirement age have substantially lower wealth levels than married couples as a result of lack of adequate financial literacy. However, the authors argue that decision-making within couples is sensitive to the relative education level of the spouses for both men and women.

\section{Research Methodology and Data Collection}

\subsection{Population and Sampling Design}

The population of the study comprised of members of occupational pension schemes in Kenya. The regulator of the retirement benefits sector in Kenya (Retirement Benefits Authority; RBA) provided the sampling frame that reported 1308 pension schemes with an estimated membership of 2 million. A sample of 2395 active members 
was drawn in stages. The schemes were first clustered in eight provinces namely; Nairobi, Central, Rift Valley, North Eastern, Eastern, Coast, Western and Nyanza as registered by the Retirement Benefits Authority. Purposive sampling was then used to determine the number of participating schemes with a condition to include at least $40 \%$ of the schemes in every province since some provinces had very few schemes. The participating schemes were then randomly drawn from the sample. Proportionate stratification was used to select the number of members to participate in the survey from each scheme. The participating members were then randomly selected at the data collection stage with a condition to include at least one trustee (member of the pension scheme's board) from each scheme. Data was collected between 19 August and 31 October 2010. The eventual sample comprised 1549 members, representing a $65 \%$ response rate.

\subsection{Questionnaire}

The purpose of the study was to determine whether pension finance literacy differ significantly in Kenya on the basis of the variables determined in other studies namely; age, education level, gender, job experience, management level, income and marital status. Four other variables observed in Kenya namely; pension plan design, participation in previous finance or pension literacy program, membership in a pension plan board and area of specialization were included to enrich the study. The questionnaire used in data collection had two sections. The first section sought to determine the independent variables while the second section contained a six question quiz on pension finance matters that the respondents were required to answer on the spot without assistance from other respondents or the interviewer.

\subsection{Validity and Reliability of the Questionnaire}

The questionnaire's content validity was guaranteed by the inclusion of items that were supported by literature review as predictors of financial literacy (section 2.3). Additionally, the quiz, included items that tested specific form of knowledge, ability or skills to apply the knowledge and perceived knowledge as recommended in Hung, Parker \& Yoong (2009). Besides, the quiz questions were drawn from empirical studies (Moore, 2003; Lusardi $\&$ Mitchell, 2008) and customized to fit the Kenyan situation.

\subsection{Data Analysis}

To determine pension finance literacy levels, a binary measure of literacy advanced by Moore (2003); Lusardi \& Mitchell (2008); Hung, Parker \& Yoong (2009) was used. The methodology involves contextualizing basic literacy questions which respondents answer. The quiz used in the current survey included six questions. Based on their responses, individuals were separated in to a "low" literacy group $(0-3$ correct answers) and a "high" literacy group ( $4-6$ correct answers). The pension literacy quiz asked the respondents; whether it was possible for an investment in ordinary shares listed at the stock exchange to reduce in value after six months, the product to invest in to have the highest expected long-term growth (ordinary shares or treasury bills), required them to identify their pension scheme designs, (defined contribution or defined benefit), asked whether members are allowed to borrow from the pension scheme, asked the persons who elect pension scheme trustees (members alone, sponsors alone, RBA or a combination of sponsors and members) and whether members can withdraw $50 \%$ of their savings from pension schemes to attend to their personal emergencies. These questions were borrowed from Moore (2003) and Lusardi \& Mitchell (2008) and contextualized to fit the Kenyan scenario. Percentage scores for each of the respondents were calculated. One way ANOVA was used to test whether the means of the pension literacy scores differ significantly on the basis of the independent variables. Post Hoc analysis was conducted by use of the Tukey approach using SPSS version 15.

\section{Findings and Discussion}

\subsection{Demographic Composition of the Sample}

Table 1 shows that most of the respondents were male (58.6\%), were aged between 30 and $35(27.2 \%)$, have university education (46.3\%), are predominantly married $(70.9 \%)$, in the middle management $(53.4 \%)$, are not board members of their pension plans $(80.2 \%)$, were specialized in business courses $(54.6 \%)$, in the monthly income levels of between Ksh. $20001-40000$ (22.6\%) with job experience ranging from 6 to 10 years (30.7\%) and had not attended to any form of pension finance literacy education.

\subsection{Pension Finance Literacy Scores}

The overall pension literacy rate amongst the respondents is $53.7 \%$ (standard deviation 0.255 ) as reported in table 2. Regarding the specific literacy questions table 2 discloses that $60.3 \%$ (standard deviation 0.489 ) knew that stocks can have a value less than the cost six months after purchase, $27 \%$ (standard deviation 0.444 ) knew that investment in stocks give long-term returns compared to the treasury bills, $72.5 \%$ (standard deviation 0.447 ) were aware of their pension designs, $65.8 \%$ (standard deviation 0.474 ) knew that they are not allowed to borrow from their pension schemes, $41.2 \%$ (standard deviation 0.492) knew that the pension board trustees are appointed by both the members and the sponsors while $55.1 \%$ (standard deviation 0.498 ) knew that it was not possible to withdraw pension benefits prematurely. Each of the responses has a range of $100 \%$ with $4.8 \%$ of the respondents having answered all questions wrongly and 5.7\% having answered all the questions correctly. An analysis of the respondents who answered at least one question correctly shows that, $10.3 \%$ answered one, 
$15.6 \%$ answered two, $24.5 \%$ answered three, $15.4 \%$ answered four and $16.2 \%$ answered five. The results indicate a normal distribution that is slightly skewed to the right.

\subsection{Determinants of Pension Finance Literacy}

One way Anova results in table 3 show significant differences in the pension finance literacy levels on the basis of education level, gender, management level, income, pension plan design, participation in previous finance education, and membership in a pension plan board (trustee) $(\alpha<0.01)$ while age, job experience and area of specialization were significant at $\alpha<0.05$. The results are consistent with previous studies. The only variable in which significant differences in the level of pension finance literacy was not noted was marital status. This result contrasts with Bell et al (2005) who find married workers outperforming unmarried ones in terms of pension awareness and knowledge. In Kenya therefore, the marital status does not influence the level of pension literacy. With regard to the variables that did not require post hoc analysis namely; gender, pension plan design, participation in previous education and membership to the pension plan board; men had higher literacy scores than women (mean 56.2\%, 50.1\% respectively) confirming the findings in Chen \& Volpe (2002) and Arnone (2004), members of defined contribution designs had higher literacy scores than those in defined benefit designs (mean 64.6\%, 31.3\% respectively), those who had participated in previous pension finance education had higher literacy scores (mean 63.4\%; 47.3\% respectively) and pension plan board members had higher literacy scores than the other members (mean $61.3 \% ; 51.8 \%$ respectively) since RBA's training targets them (Mutuku, 2007).

\subsection{Post Hoc Analysis}

Post hoc analysis summarized in table 4 shows that pension literacy differs significantly between the age groups $24-29$ and $42-47$ (mean 50.2\%, 58.1\% respectively) $(\alpha<0.05)$. The finding confirms the assertions of Arnone (2004); Bell et al (2005), RBA (2005) and Edmiston \& Gillet-Fisher (2006) who argue that older employees are likely to have more exposure and hence higher pension finance literacy. Post hoc analysis in table 5 shows that pension finance literacy levels do not differ significantly between those with primary education and secondary education (mean $35.6 \% ; 42.3 \%$ respectively). The literacy levels however differ significantly between those with primary and secondary education on one hand and those with college and university education on the other $(\alpha<$ 0.01). These findings confirm those in Lerman \& Bell (2006) and Hastings et al (2011) who document that education exposes individuals and enables them to learn and acquire knowledge in different spheres of life. Further, Post Hoc analysis (table 6) discloses that pension plan workers with less than 5 years of work experience have significantly lower pension literacy scores (mean 49.6\%) compared to those with more experience $(6-10$, mean $54.6 \%$; $11-15$, mean $55.7 \%$; $16-20$, mean $54.6 \% ; 20+$, mean $53.9 \%)$. On the basis of the management level; table 7 shows that the literacy levels differ significantly between top, middle and lower management levels (mean 65\%, 55.2\% and 49.8\% respectively) confirming the findings in RBA (2005) and Edmiston \& Gillet-Fisher (2006). Regarding the specialization of the respondents, the mean pension finance literacy scores differ significantly between those with arts and business specializations (mean $51.2 \%$ and $55.8 \%$ respectively) although those with specialty in sciences have a lower overall score (mean 51.1\%) (table 8). On the basis of income, table 9 disclose that those who earn less than Ksh. 20000 have significantly different average pension literacy scores (mean 37.5\%) than those who earn 20 001-40 000 (mean, 48.3\%), 40 001-60 000 (mean 53.1\%), $60001-80000$ (mean 54.8\%), 80 001-100 000 (mean 58.1\%) and those who earn more than 100000 (mean 65.9\%). There is however no significant difference between the pension finance literacy scores by the 20 001-40 000 and 40 001-60 000 categories, 40 001-60 000 and 60 001-80 000 groups, 40 001-60 000 and 80 001-100 000 groups, $60001-80000$ and 80 001-100 000 groups and 80 001-100 000 and over 100000 groups. These findings are congruent with Lerman \& Bell (2006); Agnew et al (2008) and Hastings et al (2011).

\section{Limitations of the Study}

The data used in the analysis was collected from the members of the occupational pension schemes in Kenya. Although these schemes cover the majority of the population covered by the pension arrangements, it excluded those covered by the civil service pension scheme and the individual retirement schemes and so the findings cannot be generalized to all the savers in the pension industry in Kenya.

\section{Conclusion}

This paper contributes to the existing research on pension finance literacy in a developing country. The topic is particularly important because new pension products are offered continuously and the general population is increasingly being left to take responsibility for the management of their retirement welfare. The study concludes that pension finance literacy amongst Kenyan pension scheme members stands at $57.3 \%$ with approximately $4.9 \%$ of the population being completely illiterate and $5.7 \%$ being fully literate. These literacy levels are low given that the respondents were drawn from the formal sector (employees in formal employment). The conjecture is that amongst the workers in the informal sector who form $75 \%$ of the working population in Kenya could be having far less pension finance literacy levels. The pension finance literacy levels differ significantly on the basis of age, education level, gender, number of years of service, management level, income, pension plan design, participation in previous finance or pension literacy program, membership in a pension plan board and area of specialization. These findings call for policy makers to develop pension finance literacy programs that 
cater for the specific needs of the distinct niches identified in the study. Pension finance programs should be customized for different age groups, education levels, gender, the number of years of service, management levels, income, pension plan designs, those who have already participated in prior pension finance programs, trustees and area of specialization. Specifically, most pension finance literacy efforts should be directed to the younger employees who form a large proportion of the workers so that they make early rightful retirement decisions. Moreover, new workers should be oriented to the pension arrangements at the work place to captivate their interest in pension finance. Additionally, much effort in training should be geared towards pension investments and operations as lower levels of literacy are recorded in these topics. Further research efforts should be devoted to the determination of the specific training needs required for the groups identified and a replication of the study with respondents being drawn from the informal sector.

\section{References}

Agnew, J., Szykman, L., Utkus, P., \& Young, J. (2007). Literacy, Trust and 401 (K) Savings Behavior, Center for Retirement Research. [Online] Available: http://escholarship.bc.edu/retirement_papers/155/ (February 15, 2011).

Arnone, W. (2004). Educating Pension Plan Participants. Pension Research Council. University of Pennsylvania.

Bell, E., Carrasso, A., \& Steuerle, E. (2005). Strengthening Private Sources of Retirement Savings for Low-Income Families. Urban Institute. Available: http://www.urban.org/uploadedpdf/311229_private_sources.pdf (March 4, 2011).

Besley, T., \& Prat, A. (2005). Credible Pensions. Fiscal Studies, 26(1), 119-135, doi:10.1111/j.1475-5890.2005.00006.x, http://dx.doi.org/10.1111/j.1475-5890.2005.00006.x

Calvert, L, Campbell, J., \& Sodini, P. (2005). Down or Out: Assessing the Welfare Costs of Household Investment Mistakes. Harvard University: Working Paper.

Chen, H., \& Volpe R. (2002). Gender Differences in personal financial literacy among college students. Financial Services Review, 11, 289-307.

Choi, J., Laibson, D., \& Madrian, B. (2005). Saving for Retirement on the Path of Least Resistance, Harvard University: Working [Online] Available: http://www.hks.harvard.edu/fs/bmadria/Documents/Madrian\%20Papers/Saving\%20for\%20Retirement\%20on\%2 0the\%20Path\%20of\%20Least\%20Resistance.pdf (February 26, 2011).

Department for International Development. (2008). UK Backs lessons in Banking to Help Africa's Poor. [Online] Available: www.dfid.gov.uk/news/files/alexander-lessons-in-banking.asp (February 1, 2011).

Edmiston, K., \& Gillet-Fisher, M. (2006). "Financial Education at the workplace" Community Affairs, Working Paper 06-02. [Online] Available: http://www.kc.frb.org/publicat/cap/gillettfisher_edmiston_financial_education_april_2006.pdf (February 1, 2011).

Fonseca, R., Mullen, K.., Zamarro, G., \& Zissimopoulos, J. (2010). What explains the gender gap in financial literacy: The role of household decision-making. Rand. WR-762. [Online] Available: http://www.rand.org/pubs/working_papers/2010/RAND_WR762.pdf (February 1, 2011).

Hastings, J., \& Mitchell, O. (2011). How Financial Literacy and Impatience Shape Retirement Wealth and Behaviors. NBER Working Paper. [Online] Available: http://www.nber.org/papers/w16740.pdf. (March 16, 2011).

Hastings, J., Mitchell, O., \& Chyn, E. (2011). Financial Literacy and Pension Fund Fees. TIAA-CREF institute. [Online] Available: http://www.tiaa-crefinstitute.org/pdf/research/trends_issues/ti_financialpension0211.pdf. (March 6, 2011).

Hung, A., Parker, A., \& Yoong, J. (2009). Defining and Measuring Financial Literacy, RAND Working Paper Series WR-708. [Online] Available: http://www.rand.org/pubs/working_papers/2009/RAND_WR708.pdf (February 18, 2011).

James, E. (2009). The Case for Financial Literacy in Developing Countries, World Bank/OECD/DFID. [Online] Available: http://www.oecd.org/dataoecd/35/32/43245359.pdf. (March 6, 2011).

Kakwani, N., Sun, H., \& Hinz, R. (2006). Old-Age Poverty and Social Pensions in Kenya. International Poverty Center, Working Paper No. 24.

Kefela, G. (2010). Promoting Access to Finance by Empowering Consumers - Financial Literacy in Developing Countries. Education Research Reviews, 5 (5), 205 - 212.

Landerretche, O \& Martinez, C. (2011). Voluntary Savings, Financial Behavior and Pension Finance Literacy: Evidence from Chile. [Online] Available: www.econ.uchile.cl/SDT (March 9, 2011).

Lerman, R., \& Bell, E. (2006). Financial Literacy Strategies: Where do we go from here? The Urban Institute, 
Report No. 1. [Online] Available: www.papers.ssrn.com/so/3/Delivery.../ssrn_ID923448_Code545810.pdf? (March 6, 2011).

Lusardi, A, Mitchell, O., \& Curto, V. (2010). Financial Literacy among the Young. Journal of Consumer Affairs, Summer, $\quad 358 \quad 380 . \quad$ doi:10.1111/j.1745-6606.2010.01173.x, http://dx.doi.org/10.1111/j.1745-6606.2010.01173.x

Lusardi, A. (2006). Financial Literacy and Financial Education Review and Policy Implications: Networks Financial Institute. [Online] Available: http://www.networksfinancialinstitute.org/Lists/Publication\%20Library/Attachments/27/2006-PB-11_Lusardi.pd f. (March 5, 2011)

Lusardi, A., \& Mitchell, O. (2006). Financial Literacy and Retirement Preparedness: Evidence and Implications for Financial Education. Michigan Retirement Research Center. WP 2006-144.

Messy, F. (2009, 8 October). OECD Financial Education Principles. [Online] Available: http://www.oecd.org/dataoecd/8/28/44409678.pdf (February 6, 2011).

Moore, D. (2003). Survey of Financial Literacy in Washington State: Knowledge, Behavior, Attitudes and Experiences", in, Social and Economic Sciences Research Center. Technical Report. N 03 - 39: Washington State University.

Mutuku, N. (2007). Financial Education Campaigns and Pension Reform: Kenyan Experience in Training Trustees, Retirement Benefit Authority. [Online] Available: http://www.rba.go.ke/docs/about/Commemorative_Book.pdf (February 26, 2011).

OECD. (2008). Recommendation on Good Practices for Financial Education relating to Private Pensions, OECD Publishing. [Online] Available: http://www.oecd.org/dataoecd/4/21/40537843.pdf (March 8, 2011)

RBA. (2005). Members Survey - 2004. Retirement Benefit Authority. [Online] Available Retirement Benefit Authority.

Available: http://www.rba.go.ke/docs/publications/RBA\%20Member\%20Survey\%202005.pdf (12 February 2011). (February 11, 2011).

RBA. (2006). Members Survey - 2005. Retirement Benefit Authority. [Online] Available: http://www.rba.go.ke/docs/publications/RBA\%20Member\%20Survey\%202005.pdf (February 12, 2011).

RBA. (2007). Trustees Survey 2007. Retirement Benefits Authority [Online] Available: http://www.rba.go.ke/page.asp?id=633 (February 12, 2011).

RBA. (2008). Report on Retirees and Pensioners Survey. Retirement Benefits Authority. [Online] Available: http://www.rba.go.ke/page.asp?id=633 (February 12, 2011).

RBA. (2009). Report on Retirees' and Pensioners' Survey. Retirement Benefits Authority Available: http://www.rba.go.ke/docs/publications/Pensioners\%27_Survey_Report\%20-\%20Final.pdf. (February 12, 2011).

Remund, D. (2010). Financial Literacy Explicated: The Case for a Clearer Definition in an Increasingly Complex Economy, Journal of Consumer Affairs, Summer, 276 - 295. doi:10.1111/j.1745-6606.2010.01169.x, http://dx.doi.org/10.1111/j.1745-6606.2010.01169.x

Skog, J. (2006). Who Knows What about their Pensions? Financial Literacy in the Chilean Individual Account System, Population for Aging Research Center: PARC Working Paper.

Stewart, F. (2006). The Role of Financial Education in Improving Pension Coverage Ratios. OECD Publishing.

Tippet, J., \& Kluvers, R. (2007). A Practical Evaluation of an Adult Financial Literacy Programme. International Review of Business Research Papers, 3, 442 - 455.

Worthington, A. (2005). Debt as a Source of Financial Stress in Australian Households. International Journal of Consumer Studies, 2, $201-222$.

Zissimopoulos, J., Karney, B., \& Rauer, A. (2008). Marital Histories and Economic Well-Being. MRRC Working Paper. 2008-180. [Online] Available: http://www.rand.org/content/dam/rand/pubs/working_papers/2008/RAND_WR645.pdf (March 28, 2011). 
Table 1. Demographic composition of the sample

\begin{tabular}{|c|c|c|c|}
\hline \multicolumn{2}{|c|}{ Demographic characteristic } & \multirow{2}{*}{$\begin{array}{c}\text { Frequency } \\
907\end{array}$} & \multirow{2}{*}{$\begin{array}{r}\text { Percentage } \\
58.6\end{array}$} \\
\hline Gender & Male & & \\
\hline & Female & 642 & 41.4 \\
\hline \multirow[t]{7}{*}{ Age } & $18-23$ & 26 & 1.7 \\
\hline & $24-29$ & 245 & 15.8 \\
\hline & $30-35$ & 422 & 27.2 \\
\hline & $36-41$ & 381 & 24.6 \\
\hline & $42-47$ & 271 & 17.5 \\
\hline & $48-53$ & 148 & 9.6 \\
\hline & 54 and above & 56 & 3.6 \\
\hline \multirow[t]{4}{*}{ Marital status } & Single & 393 & 25.4 \\
\hline & Married & 1099 & 70.9 \\
\hline & Separated or divorced & 28 & 1.8 \\
\hline & Widowed & 29 & 1.9 \\
\hline \multirow[t]{4}{*}{ Education level } & Primary school & 15 & 1.0 \\
\hline & Secondary school & 184 & 11.9 \\
\hline & Tertiary level & 634 & 40.9 \\
\hline & University degree & 716 & 46.2 \\
\hline \multirow[t]{3}{*}{ Specialization } & Arts except business & 326 & 21.0 \\
\hline & Sciences & 378 & 24.4 \\
\hline & Business & 845 & 54.6 \\
\hline \multirow[t]{3}{*}{ Management level } & Top management & 102 & 6.6 \\
\hline & Middle management & 827 & 53.4 \\
\hline & Lower management & 620 & 40.0 \\
\hline \multirow[t]{2}{*}{ Membership of pension board } & Trustee & 306 & 19.8 \\
\hline & Non-trustee & 1243 & 80.2 \\
\hline \multirow[t]{2}{*}{ Participated in pension training } & Participated & 612 & 39.5 \\
\hline & Not participated & 937 & 60.5 \\
\hline \multirow[t]{5}{*}{ Job experience (years) } & $<5$ & 327 & 21.1 \\
\hline & $6-10$ & 476 & 30.7 \\
\hline & $11-15$ & 295 & 19.0 \\
\hline & $16-20$ & 230 & 14.8 \\
\hline & $>20$ & 221 & 14.3 \\
\hline
\end{tabular}

Table 1 shows the demographic information of the respondents. 
Table 2. Pension literacy quiz and scores

\begin{tabular}{|l|l|l|c|c|}
\hline Question & Answer & $\begin{array}{l}\text { \% } \\
\text { Correct }\end{array}$ & $\begin{array}{l}\text { Standard } \\
\text { deviation }\end{array}$ & Range \% \\
\hline $\begin{array}{l}\text { If your pension scheme invested Ksh. 100 000 in } \\
\text { shares of a company, it would be possible to have } \\
\text { the shares valued less than Ksh. } 100 \text { 000 after six } \\
\text { months. (True, False, Not sure) }\end{array}$ & 60.3 & 0.489 & 100 \\
\hline $\begin{array}{l}\text { Which of the following products would your } \\
\text { pension scheme invest in to earn the highest } \\
\text { expected long term growth? (Stocks, Treasury bill, } \\
\text { not sure) }\end{array}$ & Stocks & 27.1 & 0.444 & 100 \\
\hline $\begin{array}{l}\text { What is your pension scheme's design (defined } \\
\text { benefit, defined contribution, I don't know) }\end{array}$ & $\begin{array}{l}\text { DB or DC } \\
\text { depending on the } \\
\text { scheme }\end{array}$ & 72.5 & 0.447 & 100 \\
\hline $\begin{array}{l}\text { Are members of your pension scheme allowed to } \\
\text { borrow loans from the scheme? (Yes, No, Not sure) }\end{array}$ & No & 65.8 & 0.474 & 100 \\
\hline $\begin{array}{l}\text { Who appoints trustees of your pension board? } \\
\text { (sponsor, members, both sponsors and members, } \\
\text { RBA) }\end{array}$ & $\begin{array}{l}\text { Depends on the } \\
\text { scheme but not } \\
\text { RBA }\end{array}$ & 41.2 & 0.492 & 100 \\
\hline $\begin{array}{l}\text { I can withdraw 50\% of my pension before } \\
\text { retirement to attend to an emergency (True, False, } \\
\text { Not sure) }\end{array}$ & No & 55.1 & 0.498 & 100 \\
\hline
\end{tabular}

Table 2 documents the questions that the respondents were asked to answer, the percentage of respondents who answered the questions correctly, the standard deviation and the range. The overall correct score was $57.3 \%$, standard deviation 0.255 , range $100 \%$ (4.9\% did not get any of the answers correct while $5.7 \%$ got all the answers correct). 
Table 3. ANOVA Test

\begin{tabular}{|c|c|c|c|c|c|}
\hline Factor & & Sum of squares & Mean square & F-value & Sig. value \\
\hline \multirow[t]{3}{*}{ Age } & Between groups & 1.246 & 0.208 & \multirow[t]{3}{*}{3.220} & \multirow[t]{3}{*}{$0.004 *$} \\
\hline & Within groups & 99.474 & 0.065 & & \\
\hline & Total & 100.72 & & & \\
\hline \multirow[t]{3}{*}{ Education level } & Between groups & 5.565 & 1.855 & \multirow[t]{3}{*}{30.118} & \multirow[t]{3}{*}{$0.000^{* *}$} \\
\hline & Within groups & 95.155 & 0.062 & & \\
\hline & Total & 100.72 & & & \\
\hline \multirow[t]{3}{*}{ Gender } & Between groups & 1.414 & 1.414 & \multirow[t]{3}{*}{22.027} & \multirow[t]{3}{*}{$0.000 * *$} \\
\hline & Within groups & 99.306 & 0.64 & & \\
\hline & Total & 100.72 & & & \\
\hline \multirow[t]{3}{*}{ Job experience } & Between groups & 0.712 & 0.178 & \multirow[t]{3}{*}{2.748} & \multirow[t]{3}{*}{$0.027^{*}$} \\
\hline & Within groups & 100.008 & 0.065 & & \\
\hline & Total & 100.72 & & & \\
\hline \multirow[t]{3}{*}{ Management level } & Between groups & 2.459 & 1.230 & \multirow[t]{3}{*}{19.346} & \multirow[t]{3}{*}{$0.000^{* *}$} \\
\hline & Within groups & 98.261 & 0.064 & & \\
\hline & Total & 100.72 & & & \\
\hline \multirow[t]{3}{*}{ Income } & Between groups & 10.995 & 2.199 & \multirow[t]{3}{*}{37.817} & \multirow[t]{3}{*}{$0.000 * *$} \\
\hline & Within groups & 89.725 & 0.058 & & \\
\hline & Total & 100.72 & & & \\
\hline \multirow[t]{3}{*}{ Marital status } & Between groups & 0.430 & 0.143 & \multirow[t]{3}{*}{2.209} & \multirow[t]{3}{*}{0.085} \\
\hline & Within groups & 100.290 & 0.065 & & \\
\hline & Total & 100.72 & & & \\
\hline \multirow[t]{3}{*}{ Pension plan design } & Between groups & 27.909 & 27.909 & \multirow[t]{3}{*}{592.962} & \multirow[t]{3}{*}{$0.000^{* *}$} \\
\hline & Within groups & 72.812 & 0.047 & & \\
\hline & Total & 100.72 & & & \\
\hline \multirow{3}{*}{$\begin{array}{l}\text { Attended previous } \\
\text { finance education }\end{array}$} & Between groups & 9.631 & 9.631 & \multirow[t]{3}{*}{163.573} & \multirow[t]{3}{*}{$0.000^{* *}$} \\
\hline & Within groups & 91.089 & 0.059 & & \\
\hline & Total & 100.72 & & & \\
\hline \multirow[t]{3}{*}{ Area of specialization } & Between groups & 0.813 & 0.406 & \multirow[t]{3}{*}{6.288} & $0.002 *$ \\
\hline & Within groups & 99.908 & 0.065 & & \\
\hline & Total & 100.72 & & & \\
\hline Membership & Between groups & 2.206 & 2.206 & 34.673 & $0.000^{* *}$ \\
\hline pension plan board & Within groups & 98.515 & 0.064 & & \\
\hline & Total & 100.72 & & & \\
\hline
\end{tabular}

${ }^{*} \mathrm{p}<0.05 ; * * \mathrm{p}<0.01$

Table 3 indicates that pension literacy levels differ significantly on the basis of age, job experience and area of specialization at the 0.05 level of significance and education level, gender, management level, income, pension plan design, attendance to previous financial education and membership to the pension plan board at the 0.01 significance level. The pension finance literacy levels do not differ significantly on the basis of marital status. 
Table 4. Post hoc analysis for age using the Tukey method

\begin{tabular}{|c|c|c|c|c|}
\hline Age I - J & Mean I & Mean J & Mean difference (I-J) & Sig. Value \\
\hline $18-23$ and $24-29$ & 0.4487 & 0.5020 & -0.0533 & 0.950 \\
\hline $18-23$ and $30-35$ & 0.4487 & 0.5332 & -0.0845 & 0.653 \\
\hline $18-23$ and $36-41$ & 0.4487 & 0.5481 & -0.0994 & 0.460 \\
\hline $18-23$ and $42-47$ & 0.4487 & 0.5812 & -0.1325 & 0.146 \\
\hline $18-23$ and $48-53$ & 0.4487 & 0.5282 & -0.0795 & 0.762 \\
\hline $18-23$ and $54+$ & 0.4487 & 0.4851 & -0.0364 & 0.997 \\
\hline $24-29$ and $30-35$ & 0.5020 & 0.5332 & -0.0312 & 0.729 \\
\hline $24-29$ and $36-41$ & 0.5020 & 0.5481 & -0.0461 & 0.288 \\
\hline $24-29$ and $42-47$ & 0.5020 & 0.5812 & -0.0792 & $0.008 *$ \\
\hline $24-29$ and $48-53$ & 0.5020 & 0.5282 & -0.0262 & 0.957 \\
\hline $24-29$ and $54+$ & 0.5020 & 0.4851 & 0.0169 & 0.999 \\
\hline $30-35$ and $36-41$ & 0.5332 & 0.5481 & -0.0149 & 0.982 \\
\hline $30-35$ and $42-47$ & 0.5332 & 0.5812 & -0.0480 & 0.187 \\
\hline $30-35$ and $48-53$ & 0.5332 & 0.5282 & 0.0050 & 1.000 \\
\hline $30-35$ and $54+$ & 0.5332 & 0.4851 & 0.0481 & 0.838 \\
\hline $36-41$ and $42-47$ & 0.5481 & 0.5812 & -0.0331 & 0.658 \\
\hline $36-41$ and $48-53$ & 0.5481 & 0.5282 & 0.0199 & 0.984 \\
\hline $36-41$ and $54+$ & 0.5481 & 0.4851 & 0.0630 & 0.594 \\
\hline $42-47$ and $48-53$ & 0.5812 & 0.5282 & 0.0530 & 0.388 \\
\hline $42-47$ and $54+$ & 0.5812 & 0.4851 & 0.0961 & 0.134 \\
\hline $48-53$ and $54+$ & 0.5282 & 0.4851 & 0.0431 & 0.934 \\
\hline
\end{tabular}

${ }^{*} \mathrm{p}<0.05 ; * * \mathrm{p}<0.01$

Table 4 shows that the pension literacy level is not significantly different across the age groups except between the age groups $24-29$ and $42-57$.

Table 5. Post hoc analysis for education level using the Tukey method

\begin{tabular}{|l|l|l|r|l|}
\hline Education level I-J & Mean I & Mean J & Mean difference (I-J) & Sig. Value \\
\hline Primary and high school & 0.3556 & 0.4230 & -0.0674 & 0.742 \\
\hline Primary and college & 0.3556 & 0.5105 & -0.1549 & $0.000^{* *}$ \\
\hline Primary and university & 0.3556 & 0.5929 & -0.2373 & $0.001^{*}$ \\
\hline High school and college & 0.4230 & 0.5105 & -0.0875 & $0.000^{* *}$ \\
\hline High school and university & 0.4230 & 0.5929 & -0.1699 & $0.000^{* *}$ \\
\hline College and university & 0.5105 & 0.5929 & -0.0824 & $0.000^{* *}$ \\
\hline
\end{tabular}

$* \mathrm{p}<0.05 ; * * \mathrm{p}<0.01$

Table 5 discloses that the pension literacy levels differ significantly on account of the education level of the participants since those with college and university education record higher pension finance literacy scores than those with primary and high school education. There is however no significant difference between the pension finance literacy levels amongst those with primary school and high school education levels. 
Table 6. Post hoc analysis for job experience using the Tukey method

\begin{tabular}{|l|l|l|r|l|}
\hline Job experience (years) I-J & Mean I & Mean J & Mean difference (I-J) & Sig. Value \\
\hline$<5$ and $6-10$ & 0.4964 & 0.5462 & -0.0498 & $0.002^{*}$ \\
\hline$<5$ and $11-15$ & 0.4964 & 0.5565 & -0.0601 & 0.068 \\
\hline$<5$ and $16-20$ & 0.4964 & 0.5464 & -0.0500 & 0.152 \\
\hline$<5$ and $20+$ & 0.4964 & 0.5392 & -0.0428 & 0.302 \\
\hline $6-10$ and $11-15$ & 0.5462 & 0.5565 & -0.0103 & 0.983 \\
\hline $6-10$ and $16-20$ & 0.5462 & 0.5464 & -0.0002 & 1.000 \\
\hline $6-10$ and $20+$ & 0.5462 & 0.5392 & 0.0070 & 0.997 \\
\hline $11-15$ and $16-20$ & 0.5565 & 0.5464 & 0.0101 & 0.991 \\
\hline $11-15$ and $20+$ & 0.5565 & 0.5392 & 0.0173 & 0.941 \\
\hline $16-20$ and $20+$ & 0.5464 & 0.5392 & 0.0072 & 0.998 \\
\hline
\end{tabular}

${ }^{*} \mathrm{p}<0.05 ; * * \mathrm{p}<0.01$

Table 6 shows that respondent's pension finance literacy scores increased with years of experience. The scores differed significantly amongst the respondents who had worked for less than 5 years and those who had worked for $6-10$ years at the 0.05 significance level.

Table 7. Post hoc analysis for management level using the Tukey method

\begin{tabular}{|l|l|l|r|l|}
\hline Management level I-J & Mean I & Mean J & Mean difference (I-J) & Sig. Value \\
\hline Top and lower & 0.6503 & 0.5520 & 0.0983 & $0.001^{* *}$ \\
\hline Top and middle & 0.6503 & 0.4976 & 0.1527 & $0.000^{* *}$ \\
\hline Middle and lower & 0.5520 & 0.4976 & 0.0544 & $0.000^{* *}$ \\
\hline
\end{tabular}

${ }^{*} \mathrm{p}<0.05 ; * * \mathrm{p}<0.01$

Table 7 discloses significant differences in the pension finance literacy scores amongst all levels of management.

Table 8. Post hoc analysis for the area of specialization using the Tukey method

\begin{tabular}{|l|l|l|r|l|}
\hline Specialization I-J & Mean I & Mean J & Mean difference (I-J) & Sig. Value \\
\hline Arts and sciences & 0.5123 & 0.5110 & 0.0013 & 0.998 \\
\hline Arts and business & 0.5123 & 0.5576 & -0.0453 & $0.017^{*}$ \\
\hline Business and sciences & 0.5576 & 0.5110 & 0.0466 & 0.009 \\
\hline
\end{tabular}

${ }^{*} \mathrm{p}<0.05 ; * * \mathrm{p}<0.01$

Table 9. Post hoc analysis for monthly income using the Tukey method

\begin{tabular}{|l|l|l|r|l|}
\hline Income level I-J & Mean I & Mean J & Mean difference (I-J) & Sig. Value \\
\hline$<20000$ and $20001-40000$ & 0.3750 & 0.4829 & -0.1079 & $0.000^{* *}$ \\
\hline$<20000$ and $40001-60000$ & 0.3750 & 0.5307 & -0.1557 & $0.000^{* *}$ \\
\hline$<20000$ and $60001-80000$ & 0.3750 & 0.5478 & -0.1728 & $0.000^{* *}$ \\
\hline$<20000$ and $80001-100000$ & 0.3750 & 0.5806 & -0.2056 & $0.000^{* *}$ \\
\hline$<20000$ and $100000+$ & 0.3750 & 0.6586 & -0.2836 & $0.000^{* *}$ \\
\hline $20001-40000$ and $40001-60000$ & 0.4829 & 0.5307 & -0.0478 & 0.112 \\
\hline $20001-40000$ and $60001-80000$ & 0.4829 & 0.5478 & -0.0649 & $0.021^{*}$ \\
\hline $20001-40000$ and $80001-100000$ & 0.4829 & 0.5806 & -0.0977 & $0.000^{* *}$ \\
\hline $20001-40000$ and $100000+$ & 0.4829 & 0.6586 & -0.1757 & $0.000^{* *}$ \\
\hline $40001-60000$ and $60001-80000$ & 0.5307 & 0.5478 & -0.0171 & 0.966 \\
\hline $40001-60000$ and $80001-100000$ & 0.5307 & 0.5806 & -0.0499 & 0.286 \\
\hline $40001-60000$ and $100000+$ & 0.5307 & 0.6586 & -0.1279 & $0.000^{* *}$ \\
\hline $60001-80000$ and $80001-100000$ & 0.5478 & 0.5806 & -0.0328 & 0.785 \\
\hline $60001-80000$ and $100000+$ & 0.5478 & 0.6586 & -0.1108 & $0.000^{* *}$ \\
\hline $80001-100000$ and $100000+$ & 0.5806 & 0.6586 & -0.0780 & $0.012^{*}$ \\
\hline
\end{tabular}

$* \mathrm{p}<0.05 ; * * \mathrm{p}<0.01$ 